\title{
Chapter I.8
}

\section{GEOMORPHOLOGICAL ASPECTS OF GYPSUM KARST AREAS WITH SPECIAL EMPHASIS ON EXPOSED KARST \\ Ugo Sauro}

\section{Medium- and large-sized forms}

Medium- and large-sized gypsum karst landforms are similar in many respects to those found on carbonate karst. However, there are also some differences. This chapter will review the typical landforms of gypsum karst, stressing the similarities and the differences when compared with carbonate karst forms, and discussing their morphogenetic peculiarities.

In gypsum karst areas it is also commonly possible to recognise landforms produced by erosion due to surface flow and the effects of fluvial deposition, both of which are to some degree related to the presence of lenses and layers of other rock types. Landforms produced by different types of landslides are also present.

Among the typical karst landforms, the following have been recognised:

1) dolines,

2) blind valleys,

3) polje-like depressions,

4) subsidence and collapse basins in rocks that overlie gypsum.

\subsection{Dolines}

Gypsum karst includes doline types that are similar to those developed in carbonate terrains. Authors who have described the geomorphology of gypsum karst areas have listed the following types:

1) shallow, flat floored, dolines,

2) saucer-shaped dolines,

3) bowl-shaped dolines,

4) funnel-shaped dolines,

5) pit-like dolines

6) asymmetrical slope dolines,

7) multiple or composite forms formed by the fusion of two or several simple forms,

8) chains of dolines, and corridors derived by the fusion of many dolines,

9) intermediate forms between dolines and small blind valleys.

Dolines exhibit a wide range of sizes: diameters vary from a few metres to several hundred metres; depths range from a few decimetres to nearly one hundred metres (Fig. 1).

It is noteworthy that very small dolines are present only where pure gypsum crops out, and the depressions are adjacent to each other, constituting a honeycomb karst. Populations of very small dolines have been described in the Italian Dolomites by Bini (1983) and in the western Alps 


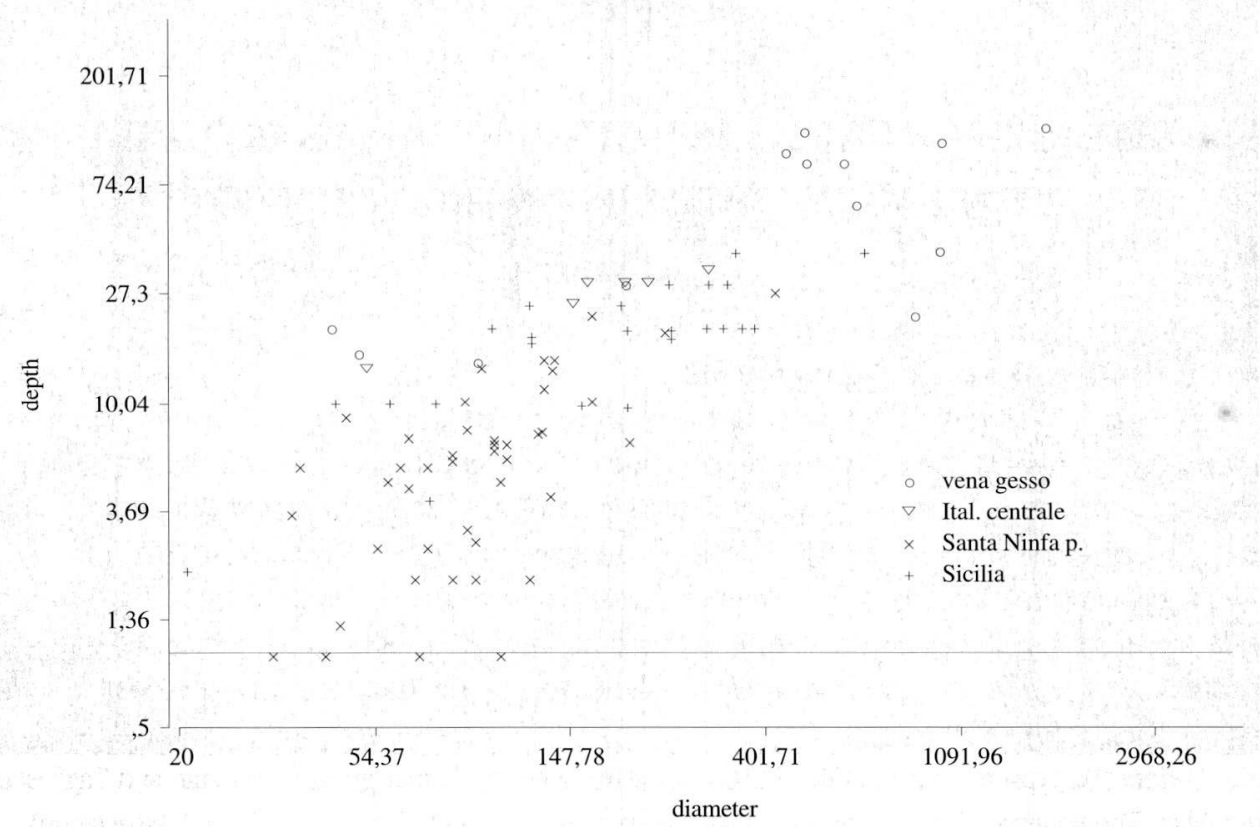

Fig. 1. Scattergram showing the inter-relations of depth to maximum diameter of some doline populations in gypsum karst areas of Italy. The scales are logarithmic $\left(\log _{e}\right)$. The data are derived from Sauro (1987) and Meneghel (in Agnesi et al., 1989). Some of the larger forms are blind valleys. The population with larger forms is that of Vena del Gesso, while the medium-sized and smaller forms are those of the Santa Ninfa plateau in Sicily, where a detailed morphometric analysis has been performed.

by Capello (1955).Typical populations of honeycomb doline karst, with dolines ranging in diameter from a few metres to several tens of metres are known in the Baisun-Tau mountain area, between the Uzbekistan and Tagikistan republics (Bernabei \& De Vivo, Eds, 1992), and in the Alps of Albania (Bassi \& Fabbri, 1996).

Intermediate features between karst and fluvial forms are probably better recognizable on gypsum than in most carbonate terrains. Many dolines also show the characteristics of small blind valleys. These forms are generally elongated to follow regional surface slopes. They display a significant difference between maximum depth (difference in elevation between the highest point of the watershed and the bottom of the depression) and minimum depth (difference in elevation between the lowest point of the rim of the depression and its floor). Basin shape is asymmetrical, with a more extended slope on the uphill side and a narrow but generally steeper slope on the downhill side.

Chains of dolines that are clearly the result of the "drying up" of fluvial valleys are also easily recognizable. In general the dolines within these multiple features are elongated along the axis of the chain (Fig. 3).

Lying between the different forms and features associated with dolines or "nested" inside 


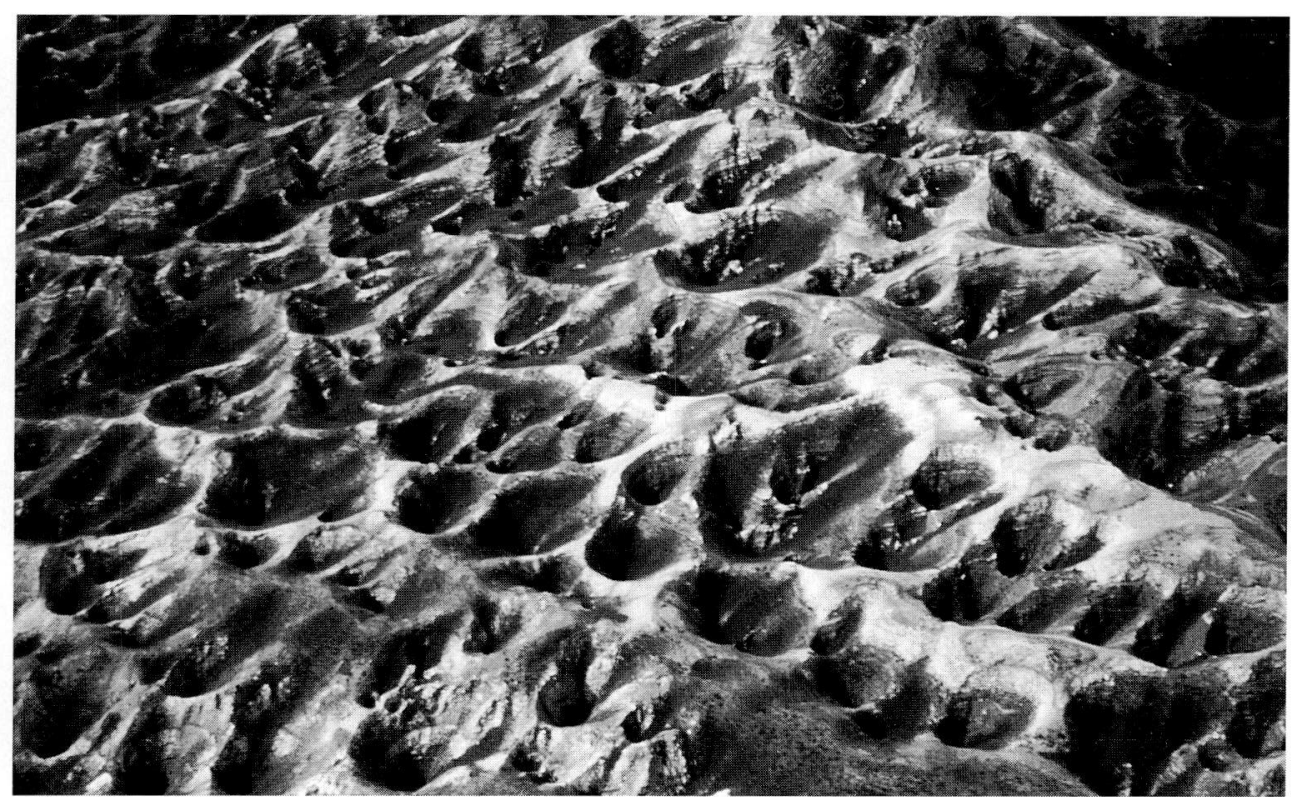

Fig. 2. View of a gypsum plateau in the Baisun-Tau mountain area, between the Uzbekistan and Tagikistan republics. The honeycomb structure of the karst depressions is evident (Photo of "La Venta" Association).

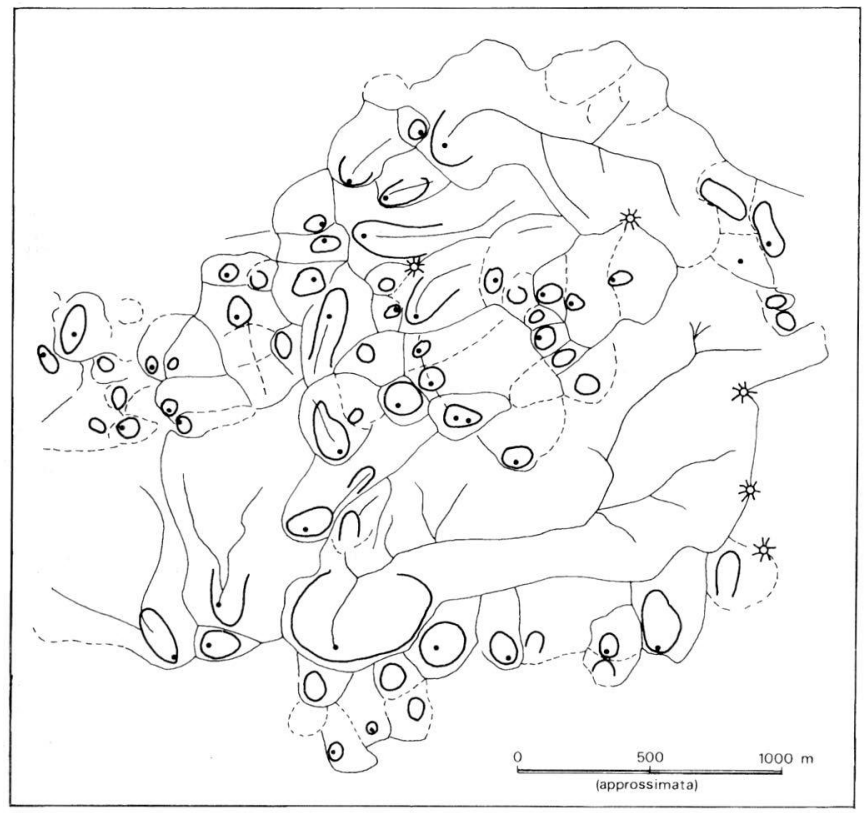

Fig. 3. Sketch of the closed landforms in the plateau area of Santa Ninfa. Typical circular dolines, blind valleys and intermediate forms are well displayed. Chains of dolines are also recognized, having developed from pre-existing blind valleys. The basin watersheds and dome-like hills are also indicated (after Agnesi et al, 1989). 
basins, are examples of small fluvial incisions (such as gorges and canyon-like valleys), different types of karren, pits or shafts, cave entrances and swallow holes.

\subsection{Blind valleys}

Several different types of blind valley have been recognized in gypsum karst:

- valleys that are cut into insoluble sediments, such as clays or other clastic materials, and end at the contact of these rocks with gypsum outcrops, where a swallow hole is active (examples are numerous in the Northern Apennines, Northern Caucasus, the Baisun-Tau mountains of central Asia, and elsewhere);

- valleys with an upstream part lying on insoluble sediments, continuing for several tens or hundreds of metres incised into gypsum outcrops, until ending at a swallow hole (as demonstrated by some valleys in Sicily, such as lo Sfondato, near Porto Empedocle);

- valleys cut completely or almost completely across gypsum outcrops (also demonstrated by some valleys in Sicily, such as the Valle del Biviere, in Santa Ninfa);

- small valleys, or valley-dolines, cut completely within gypsum outcrops, which continue downstream as chains of dolines (some valleys in Sicily in the Santa Ninfa area; see also the subchapter on dolines above).

\subsection{Polje-like depressions}

Polje-like landforms are also present in gypsum karst areas. Most of them are open, but some are partially closed around "ponors". Examples include the polje of Bambini in Greece, the open palaeo-polje of Sant Maximin in France (Nicod, 1993), and some of the poljes in Sicily (such as il Pantano, to the west of Siculiana Mare). In the Alps a glaciokarstic polje has been described (polje of La Valoire; Nicod, 1976). Polje-like depressions in intrastratal gypsum karst areas are described by Goburnova (1979). See also Chapter I.10.

\subsection{Subsidence and collapse basins in rocks overlying gypsum}

Some "karst-like forms" are induced upon non-karstic rocks by intrastratal karst development within gypsiferous and/or saliferous rock units. If underground water is able to reach such gypsum or rock salt, dissolution occurs and there is a loss of volume, creating voids in the buried sequence. As a result, both subsidence and collapse phenomena may take place, locally resulting in visible effects at the topographic surface.

Common forms that originate due to subsidence are closed basins. These may be very large but shallow, and many of them are occupied by lakes. In Sicily there are numerous lakes of this type, with surfaces ranging from a few hundred square metres to about $2 \mathrm{~km}^{2}$ (Agnesi et al, 1987; Trevisan \& Di Napoli, 1937). The lakes are susceptible to undergoing rapid changes in shape and size caused both by progression of the subsidence and by erosional processes. The Pergusa lake, near Enna in Sicily, has an area of $1.83 \mathrm{~km}^{2}$ and a maximum depth of only $4.6 \mathrm{~m}$.

Landforms that originate due to collapse are generally much smaller, but commonly show a higher depth/diameter ratio. In the braided bed of the Tagliamento River (Southern Alps), many 
collapses have occurred during the present century. The largest described was about $40 \mathrm{~m}$ in diameter and 20m in depth (Gortani, 1965). More details of karst landforms in areas of intrastratal karst, and mechanisms of collapse development, are provided in chapter I.10.

\section{Positive and/or residual forms}

Among the positive and/or residual landforms that result from the interaction between active processes (tectonic forces, gravity, weathering and denudational effects) and passive influences (lithological and structural guidance), the following may be listed:
1) outliers,
2) cone-like hills
3) dome-like hills,
4) mesa-like tabular blocks,
5) plateaux,
6) breccia pipe hills.

\subsection{Outliers}

Outliers are isolated remnants of gypsiferous rock units that are left sitting upon underlying clay rock units after the parent mass breaks into fragments that slide apart. Some of them are spectacular parallelepiped-shaped or pyramidal hills, such as the Rocca di S. Paolino, of Sutera in Sicily.

\subsection{Cone-like hills}

Cone-like hills are relatively small hills that develope inside honeycomb karst, and are comparable in appearance with the conical karst of carbonate regions.

\subsection{Dome-like hills}

Dome-like hills are more or less hemispherical hills, comprising homogeneous gypsum masses. Their origin is not yet clear, but it probably relates to flowage of gypsum in response to onesided unloading during exposure, and inhomogeneous stresses imposed by tectonics (see Chapters I.1 and I.9). Unusual weathering processes affecting the uppermost gypsum layers might also play a part in their development. Some dome-like hills have also developed due to the protective effect of thin evaporitic limestone cap rocks, which prevent dissolution of the underlying gypsum (Agnesi et al, 1989).

\section{4., 2.5. Mesa-like tabular blocks and plateaux}

The mesa-like tabular blocks and the gypsum plateaux are relatively large expanses of gypsum with nearly horizontal upper surfaces, generally delimited laterally by erosional or fault scarps. 


\subsection{Breccia pipe hills}

Breccia pipe hills are areas of relatively high relief that result from the selective denudation of breccias composed of different rock types. The breccias originate due to collapse of gypsiferous beds and other rocks into cavities formed within deep-seated gypsum beds. Such breccias commonly have a pipe-like form and locally they can offer more resistance to erosion than do the surrounding rocks.

\section{Morphogenetic aspects of dolines and dry valleys}

Morphogenetic processes producing karst landforms in gypsiferous rocks are similar to those that are active in carbonate terrains. The following types of doline have been distinguished:

1) normal solution dolines;

2) dolines originated by the evolution of a swallow hole;

3) dolines originated by collapse phenomena;

4) alluvial and/or piping dolines;

5) subsidence basins and dolines.

Whereas in many carbonate areas most dolines appear to fit within type 1), in areas of exposed gypsum most dolines seem related to type 2). On gypsum outcrops water infiltration tends to relate to a few well-defined sink points, and not to a dense system of small openings as is more common on carbonates. Probably there are two main drainage system elements: nearly horizontal, influenced by clay layers and lenses, and nearly vertical, guided by joint (and other) fissures. The typical honeycomb patterns are probably related to the latter.

The structures of epikarsts developed in carbonate and in gypsum sequences are dissimilar. In gypsum, most fractures are sealed near the surface, so most surface water penetrates and flows through a few medium-sized and large cavities. This characteristic is also indicated by the negligible storage capacities of gypsum epikarst and by the very short time lag between precipitation and peak discharge from the underground drainage systems.

Thus, the configuration of slopes within a doline in gypsum is influenced both by normal slope processes and by chemical erosion at the soil/rock or rock/atmosphere interface. However, the rock surface is not a real barrier to the water: some water is able to penetrate for a distance of between a few centimetres and a few metrers into the interstices between crystals. Interstitial water favours loss of mass, exchange of salts and recrystallization of the gypsum, and contributes to surface lowering in general.

In literature describing gypsum karst, many authors have expressed astonishment at the engulfment capacity of swallow holes in blind valleys and dolines. In many blind valleys there are large quantities of clay and gypsum fragments that are removed by streams during floods. It is difficult to understand why this material does not obstruct the underground channels, which appear to remain constantly active, even when they contain large amounts of fill. Among the possible explanations for such drainage capacity it is important to remember the process of mass wastage due to the dissolution of gypsum clasts and also, perhaps, a possible auto-lubricant capacity provided by mixtures of gypsum, solvent water and clay (Marinelli, 1917). Ghosts of gypsum pebbles have been observed in the cave deposits of Santa Ninfa in Sicily (Bini, 1989). Dissolution of origi- 


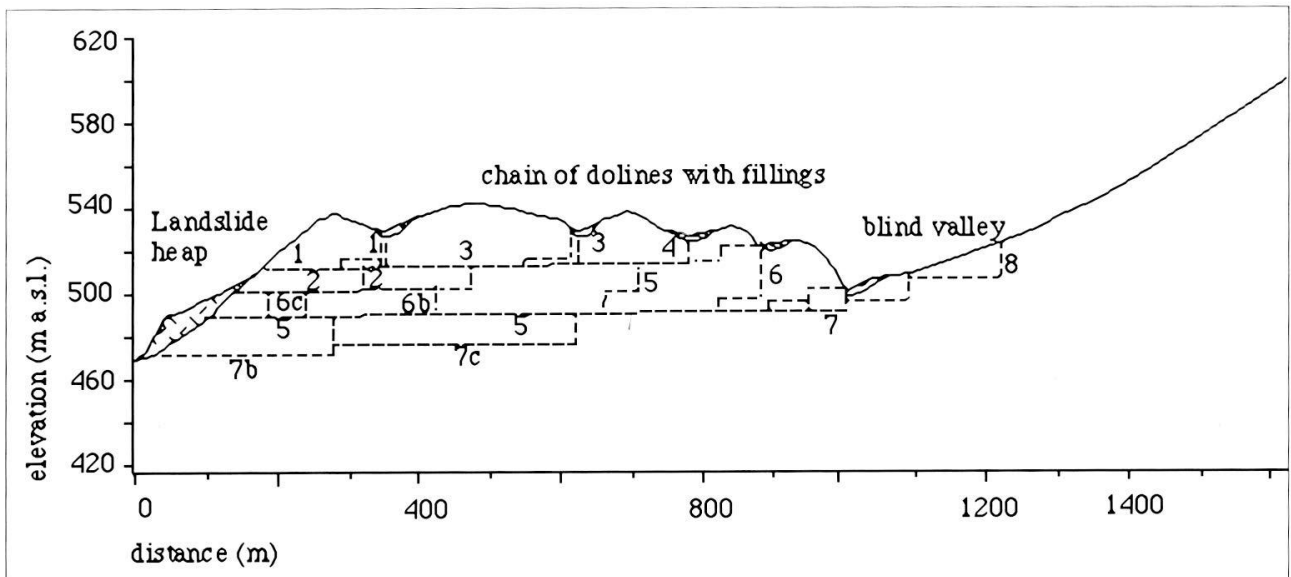

Fig. 4. Longitudinal profile of a chain of dolines following the path of a former blind valley in the Santa Ninfa plateau (Sicily). It is seen how the altitudes of the doline bottoms decrease upstream. The first and most active closed basin of the chain is an intermediate form, between a small blind valley and a doline. The form of the underground drainage network is hypothetical and reflects the possible influence of clay beds and lenses. Small springs fed by the karst system have probably induced a landslide on the scarp to the left.

nal gypsum pebbles produced pebble-shaped voids, increasing the porosity of the deposits and facilitating their erosion during floods.

In many alignments or chains of dolines, each doline seems to have originated due to development of a swallow hole at the end of a blind valley. The first doline in the chain to develop is that at the downvalley limit, while the farthest upvalley doline is the youngest and represents the end of a small, still-active blind valley.

The phenomenon of swallow point retreat within blind valleys in carbonate areas has been described in many areas, including the Classical Karst. On gypsum, it is commonly clearly observable that the slope of the longitudinal profile along a chain is counter to that of the old valley floor. This means that the altitudes of the lowest points of the bottoms decrease from the oldest to the youngest dolines in a chain (Agnesi et al, 1989; Sauro, 1995, Fig. 4).

In the Vena del Gesso of the Northern Apennines other interesting aspects of blind valleys and doline evolution are recognized. For instance, a palaeo-erosion surface cuts a homoclinal sequence that includes a thick gypsum formation. The latter rock unit is more resistant to erosion than adjacent units and tends to emerge as a structural ridge, perhaps best described as a "bevelled cuesta", dipping towards the plain of the Po. The ridge is dissected by the major valleys that provide water gaps through it, but some local water courses end as blind valleys at the contact with the gypsum ridge. Large and deep dolines are present on the ridge itself.

\section{Genetic aspects of subsidence and collapse basins}

The evolution of subsidence and collapse basins is worthy of individual study in each morphostructural situation, but only two examples are considered here. The first is that described by 


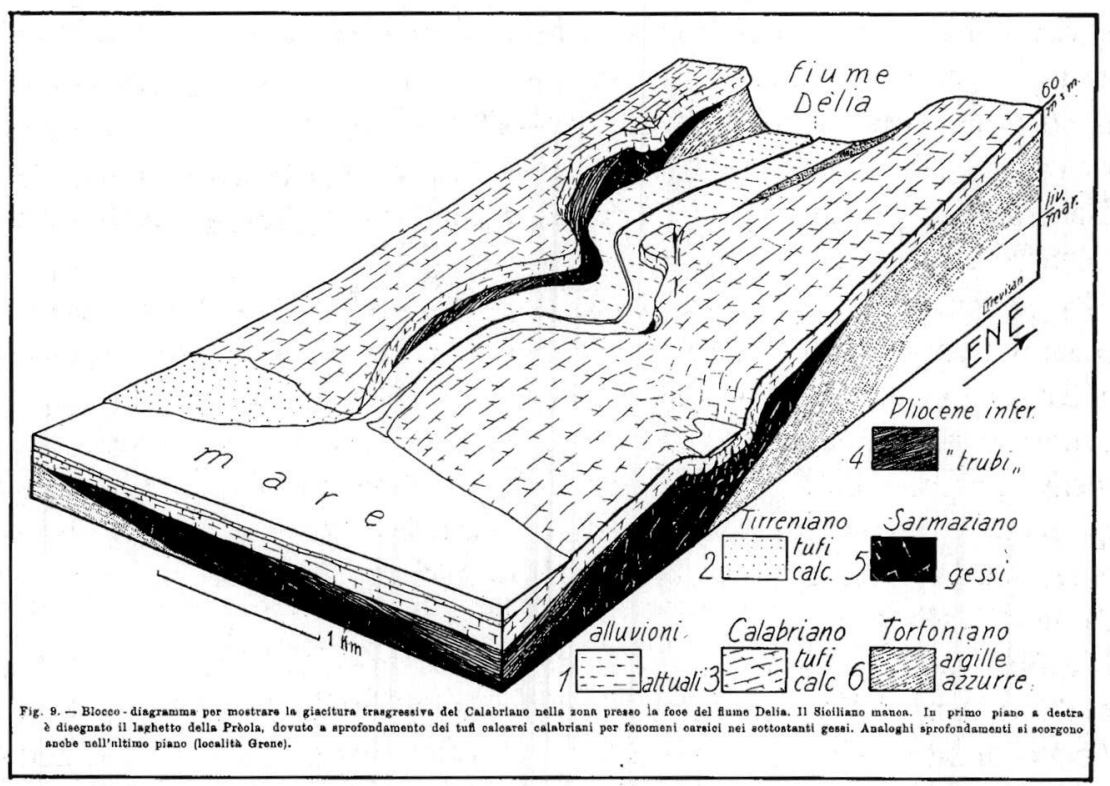

Fig. 5. The subsidence basin of Preola lake in Sicily is the result of the subsidence of a Lower Pleistocene calcarenite formation. The underlying gypsum, cut by an erosion surface, is partly dissolved by the waters of the Delia River, which infiltrated along the course of an entrenched meander (from Trevisan \& De Napoli, 1937).

Trevisan \& Di Napoli (1937), in the Preola Lake depression in Sicily. The lake basin is developed within Lower Pleistocene marine calcarenites, slightly more than $10 \mathrm{~m}$ in thickness, that cover an erosion surface cut by a marine transgression. This erosion surface cuts across a homoclinal sequence that includes about a hundred metres of gypsum. The Delia River valley has entrenched into the gypsum. Along the course of the river bed lateral circulation has favoured preferential dissolution of gypsum below the calcarenite cover, with consequent subsidence of the overlying beds and development of a closed basin (Fig. 5).

The second example is of collapse basins on the bed of the Tagliamento River in the Southern Alps. Here there are gypsum lenses covered by fluvial deposits, most of which are pebble-dominated and locally cemented to form conglomerates. Underground water within the fluvial deposits dissolves the underlying gypsum, creating cavities that induce sudden collapses, with concomitant development of ephemeral "alluvial dolines" in the river bed.

\section{Aspects of doline plateaux evolution}

Two main models for the evolution of doline plateaux in gypsum can be described by, referencered to real situations observed in Sicily. In the Santa Ninfa plateau, which consists of a gently sloping homoclinal surface delimited on three sides by scarps, some remnant outcrops of the denuded overlying rock unit remain. This is the Trubi Formation, which consists of marly limesto- 
nes and clay. A fluvial network developed here before the underlying gypsum was exposed. This network was superimposed upon the underlying gypsum, with subsequent development of a sequence of blind valleys and doline chains. Now both forms co-exist, but in some areas the dolines have colonised the entire surface and have now coalesced to produce a type of honeycomb karst. The evolutionary sequence passed from a fluvial morphology, through an entrenched karst, into a denuded karst.

On the Serra Ciminna plateau, which is a nearly tabular surface delimited on all sides by scarps, gypsum is covered (at least locally) by permeable sand and pebble deposits. The top of the gypsum is an erosion surface that was affected by karst processes both during the previous phase of exposure and after the covering episode. Water can circulate within the cover rock to dissolve the underlying gypsum. Uplift of the plateau has favoured the enlargement of fissures and the development of karren and dolines. The slopes of some dolines comprise tabular karren-covered surfaces separated by large grikes, and in other places there are miniature stone forests with rock pedestals several metres high.

No detailed study of a plateau with typical honeycomb patterns of dolines has been described. It seems that in some plateau areas (such as in the Alps of Albania) there is a nearly cylindrical pit at the bottom of each basin. It may thus be supposed that during the last stage of denudation of the overlying formations (limestones or others permeable rocks) a dense and regular network of small vertical pits (pipes) developes, probably guided by the joint network in the gypsum. This network of vertical cavities allows evacuation of gypsum solutions and sustains doline evolution.

Research described in this chapter was carried out with the help of contributions from the Ministry of University and Scientific Research (MURST 40\% and 60\%).

\section{References}

AGNESI, V., MACALUSO, T., MENEGHEL, M. \& SAURO, U. 1989. Geomorfologia dell'area carsica di S. Ninfa (Sicilia occidentale), Memorie Istituto Italiano Speleologia, s. II, 3, Palermo, pp.: 23-48.

AGNESI, V., MACALUSO, T. \& PIPITONE, G. 1987. Fenomeni carsici epigei nelle evaporiti in Sicilia, Le Grotte d'Italia, s. 4, XIII, Bologna, pp.: 123-161.

BASSI, S. \& FABBRI, I. 1996. Storia di tre spedizioni in Albania. Speloelogia, 35, 89-96.

BERNABEI, T. \& DE VIVO, A., Eds, 1992. Grotte e storie dell'Asia Centrale: le esplorazioni geografiche del progetto Samarcanda. CEV, Padova, 309 pp.

BINI, A. 1983. Appunti sul carsismo nei gessi della Formazione a Bellerophon al Passo di San Pellegrino - Dolomiti (Italia), Atti Convegno Internazionale "Carsismo di Alta Montagna", Imperia 1982, 1, pp.: 33-36.

BINI, A. 1989. Morfologia e sedimentologia ipogea delle cavità di S. Ninfa, Memorie Istituto Italiano Speleologia s. II, 3, Palermo, pp.: 101-135

CAPELLO, C.F. 1955. Il fenomeno carsico in Piemonte: le zone interne del sistema alpino, CNRRicerche di morfologia e idrologia carsica, 6, Roma, pp.: 1-140.

FORTI, P. \& GRIMANDI, P. Eds, 1986. Atti del Simposio Internazionale sul casismo delle Evaporiti. 
Le Grotte d'Italia. s.4, v.12, 420 pp.

FORTI, P., AGNESI, V. \& MACALUSO, T. Eds, 1989. I gessi di Santa Ninfa (Trapani): Studio multidisciplinare di un'area carsica. Mem. dell'Istituto Italiano di Speleologia, 3, s.2, 202 pp.

FORTI, P., AGNESI, V., MACALUSO, T. \& PANZICA LA MANNA, M. Eds, 1987. Atti del Simposio internazionale sul carsismo delle evaporiti. Il carsismo delle evaporiti in Sicilia. Palermo, 1985, Le Grotte d'Italia, s.4, v. 13, 213 pp.

FORTI, P., FRANCAVILLA, F., PRATA, E., RABBI, E., VENERI, P. \& FINOTELLI, F. 1985. Evoluzione idrogeologica dei sistemi carsici dell' Emilia-Romagna: 1- Problematica generale; 2- Il complesso Spipola - Acqua Fredda". Regione Emilia Romagna, Tip.Moderna, Bologna, pp.: 1-60.

GORTANI, M. 1965. Doline alluvionali in Carnia, Mondo Sotterraneo, Udine, pp.: 14-20.

MARINELLI, O. 1917. Fenomeni carsici nelle regioni gessose d'Italia, Materiali per lo studio sui Fenomeni. Carsici III, Memorie Geografia Suppl. Rivista Geografica Italiana 34, pp.: 263-416.

NICOD, J. 1976. Karsts des gypses et des évaporites associées.- Annales de Géographie. n471: p. $513-554$.

NICOD, J. 1992. Recherches nouvelles sur les karsts des gypses et des évaporites associées. 1ère partie: processus et cavernement.- Karstologia, $n^{\circ} 20: 1-10$.

NICOD, J. 1993. Recherches nouvelles sur les karsts des gypses et des évaporites associées seconde partie: géomorphologie, hydrologie et impact anthropique).- Karstologia n 21: p.15-30.

SAURO, U. 1987. Lo stato attuale degli studi sul carsismo nelle evaporiti in Italia, Le Grotte d'Italia, s. 4, XIII, Bologna, pp.: 93-106.

SAURO, U. 1995. - Highlights on doline evolution. In BARANY-KEVEI I. (Ed.. Environmental effects on Karst Terrains (homage to Laszlo Jackucs). Acta Geograph. Szegediensis v. 34, Univ. of Szeged, $107-121$.

TREVISAN, L., DI NAPOLI, E., 1937. Tirreniano, Siciliano e Calabriano nella Sicilia sud-occidentale. Note di stratigrafia, Paleontologia e Morfologia. Giorn. Sc. Nat. e Econ. Palermo, 39/8, 1-37. 